\title{
Effect of breed on carcass traits of Kundhi and Nili Ravi buffalo
}

Muhammad Siddique Zardari, Hubdar Ali Kaleri, Rameez Raja Kaleri", Asma Kaleri, Mushtaque Ahmed Jalbani, Azhar Hussain Kaleri, Muhammad Zeb Khan, Zahid Qadir and Faisal Ashraf

Department of Animal Breeding and Genetics and Genetics, Sindh Agriculture University, Tandojam-Pakistan.

*Corresponding author's email: rameezkaleri@gmail.com

Citation

Muhammad Siddique Zardari, Hubdar Ali Kaleri, Rameez Raja Kaleri, Asma Kaleri, Mushtaque Ahmed Jalbani, Azhar Hussain Kaleri, Muhammad Zeb Khan, Zahid Qadir and Faisal Ashraf. Effect of breed on carcass traits of Kundhi and Nili Ravi buffalo. Pure and Applied Biology. Vol. 6, Issue 1, pp267-271. http://dx.doi.org/10.19045/bspab.2017.60023

Received: 29/12/2016 Revised: 14/02/2017 Accepted: 17/02/2017

Online First: 21/02/2017

\section{Abstract}

Present study was conducted to study the carcass traits of Kundhi and Nili Ravi buffalo. The total 100 animals of Kundhi and Nili Ravi breed were randomly selected and divided into A, B, $\mathrm{C}$ and D group. In group A and C there were Kundhi and Nili Ravi male whereas, B and D females of both breeds respectively and the age of animals was around 36 months. The selected animals were slaughtered at slaughter house of Seven Star meat processing company Dhabeji, Thatta. The carcass traits studied including live body weight, carcass weight, dressing percentage and boneless weight. The results revealed that carcass traits live body weight, carcass weight, dressing percentage and boneless weight of Nili Ravi male was significantly higher $(\mathrm{P}>0.05)$ as compared to the Kundhi buffalo male, while same carcass traits were also observed highly significant $(\mathrm{P}>0.01)$ in Nili Ravi female than Kundhi buffalo female. It was concluded that carcass traits of Nili Ravi buffalo are better expressed and produces more beef than Kundhi buffalo. Likewise Kundhi buffalo male is better in beef production than the Nili Ravi female and Kundhi buffalo female produces low carcass yield.

Keywords: Carcass traits; Breed; Kundhi; Nili Ravi buffalo

\section{Introduction}

Buffalo meat being popular in most of buffalo loving countries around the world as it comes from removed animals or spare males. A well-known Swamp buffalo breed contains average live weight yields $592 \mathrm{~kg}$, $277 \mathrm{~kg}$ carcass and $215 \mathrm{~kg}$ meat [1]. Meat consumption varies worldwide, depending on cultural or religious preferences, as well as economic conditions. Vegetarians choose not to eat meat because of ethical, economic, environmental, Religious or health concerns that are associated with meat production and consumption [2]. Meat of Buffalo contains lower fat as matched with beef of cattle [3]. Breed differences in production traits are important genetic resources for improving beef production efficiency, meat composition and quality. The carcass traits are mainly affected by breed, gender, age and nutrition of animal [1]. Pakistan has 33.7 million buffalo heads with approximately 18.01 percent of total world population, it includes Kundhi and Nili Ravi 
breeds. Both breeds are renowned for their high milk and meat production. In Pakistan, both breeds have major importance, because they play an important role in the overall economy of country by contributing milk, meat, hides and draft power for various agricultural operations [4]. Therefore, the present study was planned to observe the effect of breed on carcass traits of Kundhi and Nili Ravi buffalo.

\section{Methodology}

In this study, 100 animals of Kundhi and Nili Ravi breeds with age of 36 month were selected. The selection was performed on the bases of physical characters, health and age [5]. After the selection, the live body weight of each animal was measured using the digital weighing balance at Seven Star meat processing company, Dhabeji, Thatta. The animals were slaughtered breed and group vise. The animals were slaughtered, dressed out and skinned into two halves.

\section{Dressing percentage}

The dressing percentage was calculated using the formula described by [3].

$\mathrm{DP}=($ Total carcass $\div$ Total LBW $) \times 100$

\section{Results}

\section{Breed and gender comparison between} Kundhi and Nili Ravi male

The results revealed that the carcass traits of Nili Ravi breed are better than the Kundhi. It was observed that carcass traits including live body weight, carcass weight, dressing percentage and boneless weight of Nili Ravi are significantly higher than Kundhi breed in details given in Table 1.

Table 1. Live Body weight, Carcass weight, Dressing percentage, Boneless weight of Kundhi and Nili-Ravi male

\begin{tabular}{|l|l|l|}
\hline \multirow{2}{*}{ Carcass Traits } & \multicolumn{2}{|c|}{ Breeds } \\
\cline { 2 - 3 } & Kundhi Male & Nili Ravi Male \\
\hline Live body weight $(\mathbf{k g})$ & $544.44^{*} \pm 31.76$ & $571.52^{*} \pm 41.11$ \\
\hline Carcass Weight $(\mathbf{k g})$ & $272.68^{*} \pm 21.00$ & $314.4^{*} \pm 27.62$ \\
\hline Dressing (\%) & $50.07 * \pm 2.22$ & $54.99 * \pm 2.45$ \\
\hline Boneless weight $(\mathbf{k g})$ & $133.05 \pm 15.76$ & $148.05 \pm 15.76$ \\
\hline
\end{tabular}

*Means are significantly different at $(\mathrm{P}<0.05)$

Breed and gender comparison between Kundhi and Nili Ravi female

The results revealed that the carcass traits of Nili Ravi breed are better than the Kundhi. It was observed that carcass traits including live body weight, carcass weight, dressing percentage and boneless weight of Nili Ravi was significantly higher than Kundhi breed in Table 2.

Table 2. Live Body weight, Carcass weight, Dressing percentage, Boneless weight of Kundhi and Nili Ravi female

\begin{tabular}{|l|l|l|}
\hline \multirow{2}{*}{ Carcass Traits } & \multicolumn{2}{|c|}{ Breeds } \\
\cline { 2 - 3 } & Kundhi female & Nili Ravi female \\
\hline Live body weight (kg) & $363.6^{*} \pm 25.98$ & $398.84^{*} \pm 22.12$ \\
\hline Carcass weight $(\mathbf{k g})$ & $172.96^{*} \pm 15.40$ & $207.32^{*} \pm 23.30$ \\
\hline Dressing $(\%)$ & $47.46^{*} \pm 3.30$ & $51.90^{*} \pm 4.11$ \\
\hline Boneless weigh t(kg) & $130.22^{*} \pm 11.93$ & $140.22^{*} \pm 11.96$ \\
\hline
\end{tabular}

$*$ Means are significantly different at $(\mathrm{P}<0.05)$ 
Description of carcass weight for Kundhi and Nili Ravi (male and female)

Results for carcass yield of Kundhi male and female was observed lower as compared to
Nili Ravi male and female. The results showed the significant difference $(\mathrm{P}>0.05)$ in Graph 1.

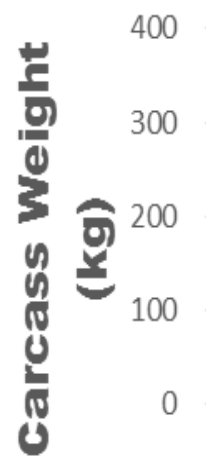

314.4

\subsection{8}
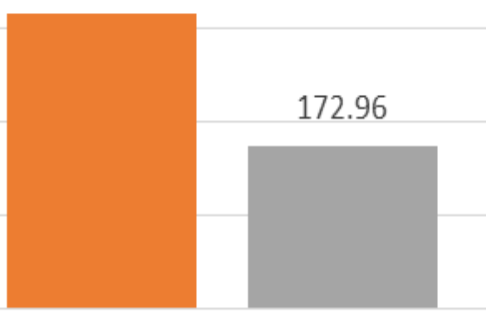

207.32

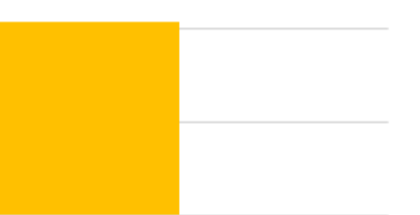

口 $\square$

\section{Graph 1. Carcass weight}

Description of dressing percentage for Kundhi and Nili Ravi (male and female) The results for the dressing percentage Kundhi male and female were observed lower as compared to Nili Ravi male and female. The results showed the linear significant difference $(\mathrm{P}>0.05)$ in Graph 2.

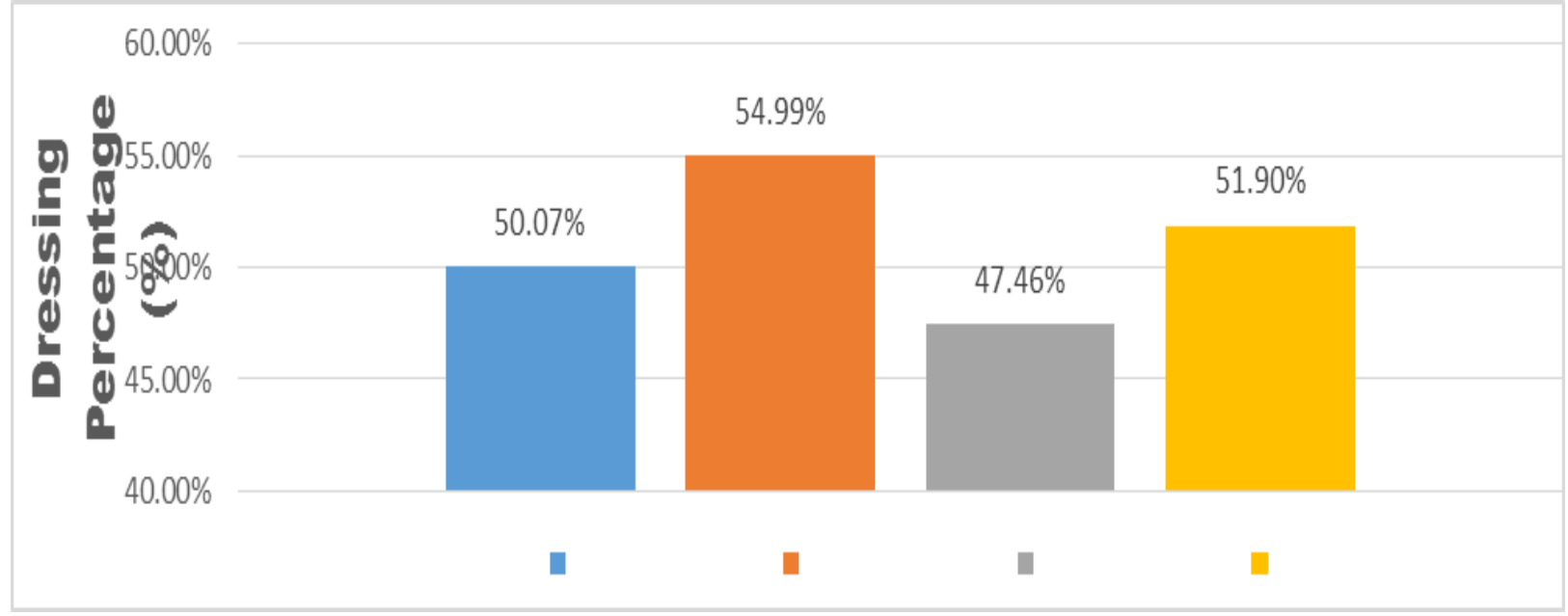

Graph 2. Dressing percentage

Description of boneless weight for Kundhi and Nili Ravi (male and female)

The results for boneless weight of both breeds while in the male of Kundhi and Nili
Ravi was observed non-significant difference $(\mathrm{P}<0.5)$ in Graph 3. 


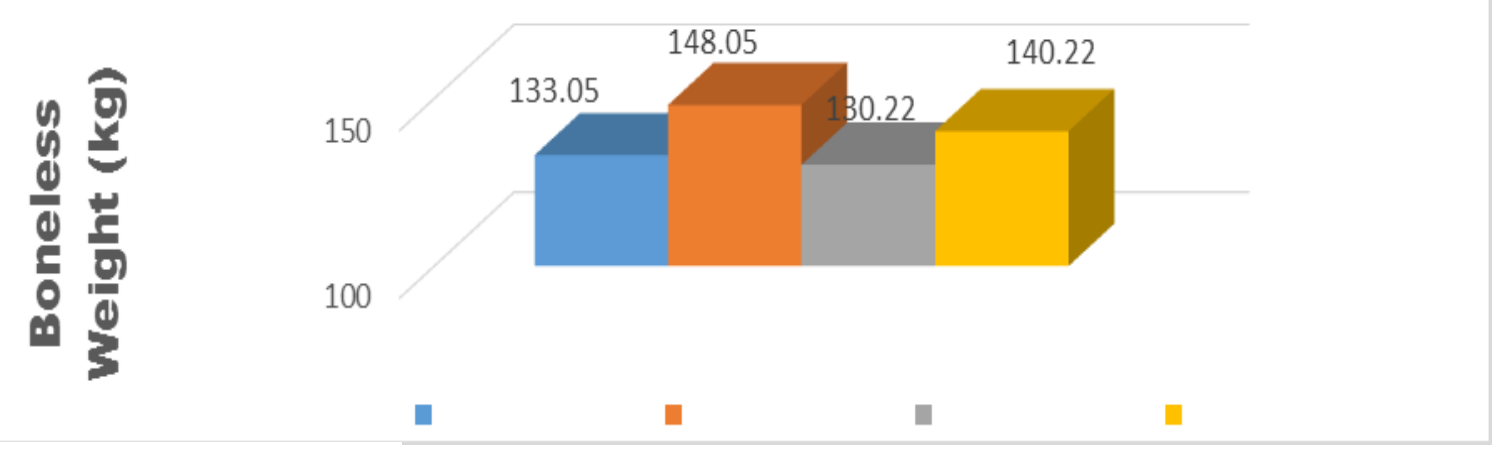

Graph 3. Boneless weight

\section{Discussion}

In the present study, the average live body weights of Kundhi male was significantly higher than the female buffalo. Similarly, Nili Ravi males were heavier than female animals respectively. Similar results were seen by $[6,7]$, who have reported that the body weight of male Nili Ravi was higher than the female Nili Ravi. It is natural phenomenon that the live body weight of adult male animals is heavier than that of the female.

\section{Carcass weight}

The carcass produced from the male of the two breeds were higher than their respective females, findings of our study are in agreement with the results of [8-10], who reported higher $7-5 \%$ higher carcass weight in male of Aryshire cattle, while lower in female of similar age. The results of $[7,11]$, are also in agreement with results of the current study, they have also reported higher carcass weight in males of Brangus cattle and lower carcass weight in females, that is due to natural phenomenon and may also be due to large amount of food intake by male.

\section{Dressing percentage}

The results of dressing percentage was higher in the males than females; however, both the males and females of Nili Ravi. Our results are in agreements with the findings of [12-14], who have reported higher carcass weight in Morucha cattle breed male as compared to female. It is believed that the highest quality beef can be harvested from animals below 36 months of age. Similarly, old cows yield very palatable beef if properly fattened and processed [7].

\section{Boneless weight}

In our study, the boneless weight from the females of the Nili Ravi breed was higher in yield than their males. However, the relations was opposite in Kundhi buffaloes, where the higher boneless weight was derived from males. The results of the currents study of Kundhi males are in agreement with the results of $[6,14,15]$, who reported reports 2.0-2.4\% more boneless weight in males as compared to the female of Herefored cows. A possible explanation of this difference could be addressed to the observations made by [16, 13], who have reported that high bone ratio and muscle thickness in bulls as opposed to the cows that are leaner and have lower bone weight, same statement repeated by [3], who have also reported $20-22 \%$ higher bone weight in male of Jersey cattle as compared to female.

\section{Conclusion}

It was concluded that carcass traits of Nili Ravi are better expressed and produces more beef in comparison to Kundhi. Kundhi male is better in beef production than the Nili Ravi female and Kundhi female produces low carcass yield.

\section{Authors' contributions}

Conceived and designed the experiments: HA Kaleri, Performed the experiments: MS Zardari, RR Kaleri, MA Jalbani \& F Ashraf, 
Analyzed the data: HA Kaleri, A Kaleri \& A $\mathrm{H}$ Kaleri, Contributed reagents/ materials/ analysis tools: MS Zardari, Z Qadir \& MZ Khan, Wrote the paper: RR Kaleri.

\section{References}

1. Barton L, Bures D \& Kudrna V (2010). Meat quality and fatty acid profile of the musculus longissimus lumborum in Czech Fleckvieh, Charolais and Charolais $\times$ Czech Fleckvieh bulls fed different types of silages. Czech Journal of Animal Science 55: 479-487.

2. Wikipedia 2013. The free encyclopedia/chapter.2/meat.htm.

3. Mckiernan BB, Gaden and Sundstrom B, (2007). Dressing percentages for cattle PRIMEFACT 340.1-3.

4. Sanjrani SN, Mirbahar KB, Soomro H \& Sahito HA (2013). Prevalence of abortion in Kundhi buffalo in district Hyderabad, Sindh - Pakistan. Herald Journal of Agriculture and Food Science Research Vol 2 (1): pp. $070-077$.

5. Shah IS, Bashir E \& Bantel (2013). Animal husbandry. National Book Foundation Islamabad 60-61.

6. Khalil SA, Safaa \& Eid LN (2004). Culled buffalo heifers as a potential source for beef production. J Agric Sci Mansoura Univ 29(9): 4903-4916.

7. Khalil, Safaa SA \& Eid LN (2004). Culled buffalo heifers as a potential source for beef production. J Agric Sci Mansoura Univ 29 (9): 4903-4916.

8. Guenther JJ, Bushman DH, Pope LP \& Morrison RD (2005). Growth and development of the major carcass tissues in beef calves from weaning to slaughter weight, with reference to the effect of plane of nutrition. $J$ Anim Sci 24: 1184.

9. Fluharty FL, Loerch SC, Turner TB, Moellerand SJ \& Lowe GD (2000).
Effects of weaning age and diet on growth and carcass characteristics in steers. J Anim Sci 78: 1759-1767.

10. Vaz FN, Vaz RZ, Pascoal LL, Restle J, Leal WS \& Avila MM (2012). Economical Analysis and Commercial Cuts Yields of Buffaloes and Bovines of Both Sexes. J Anim Prod Adv 2(10): 436-444.

11. Wheeler TL, Cundiff LV, Shackelford SD \& Koohmaraie M (2004). Characterization of biological types of cattle (Cycle VI): Carcass, yield, and longissimus palatability traits. J Anim Sci (82): 1177-1189.

12. Khalil SSA (2010). Efficiency of meat production from culled force-fed lactating buffalo. Egyptian J Anim Prod 47(1):1-10.

13. Piedrafita J, Quintanilla R, Sanudo C, Olleta JL, Campo M \& Panea B (2003). Carcass quality of 10 beef cattle breeds of the Southwest of Europe in their typical production systems. Livestock Prod Sci 82(1): 1-13.

14. Azahan EA \& Noraziah M (2001). Carcass yield and edible component parts of African black cattle raised under an intensive system in Malaysia. J Trop A \& F Sci 29(1): 99-102.

15. Dieumou FE, Adegbola TA \& Doma UD (2013). Growth performance, carcass characteristics and economics of production of Nigerian buffaloes fed diets with two sources of protein and two levels of wheat offal. Journal of cereals and Oilseeds 4(4): 42-47.

16. Kempster AJ, Cuthbertson A \& Harrington H (2003). The relationship between conformation and the yield and distribution of lean meat in the carcasses of British pigs, cattle and sheep: A review Meat Sci 6 (1): 37-53. 